\title{
The Anti-Americanism and the Spirit of European Unity
}

\author{
Daria Kazarinova
}

\begin{abstract}
The European integration process was initiated based on the model of the United States. The idea was to create a unit similar in some ways to the United States, while at the same time a unique, European entity. Anti-Americanism can be defined as the ideological tendency to resist the reproduction of American economic, social and cultural patterns. At the heart of this article is the question of whether antiAmericanism is an effective contributor to the European integration process.
\end{abstract}


The European integration process was initiated based on the model of the United States. The idea was to create a unit similar in some ways to the United States, while at the same time a unique, European entity. History reveals that the origins of European integration were inspired by the United States. In the context of post World War II, European leaders responded to the strengthening of U.S. influence in a globalizing world.

Today in Europe (the Old World), the United States (the New World) is seen differently. According to Russian political scientist Vladislav Inozemtsev, "the European non-acceptance of the USA is becoming more and more ideological." ${ }^{1}$ Most Europeans prefer to stress the political, economic, social and cultural distinctions between Europe and America. Such a frame of mind can be defined as antiAmericanism: the ideological tendency to resist the reproduction of American economic, social and cultural patterns. In this sense, anti-Americanism is not active hatred towards the United States, but rather the promotion of a distinctly European socio-cultural identity. In "The Anti-American Century” Ivan Krastev introduces two basic types of anti-Americanism: murderous anti-Americanism (such as terrorism), and "soft" anti-Americanism (such as popular belief and the media). The approach of this article is to consider anti-Americanism as defined as the resistance to the American economic, social and cultural models.

Anti-Americanism is rooted in the perception of the United States as a superpower. We must, therefore, determine if the United States is in fact a superpower. The majority of scholars agree and global public opinion considers the U.S. a unique superpower of present time. Its economic power and aggressive foreign policy, which seek to spread American cultural standards, (also known as "Americanization"), lead us

\footnotetext{
${ }^{1}$ Inozemtsev, V., Is Europe Really Possessed by Anti-Americanism?, Moscow: 2005, p. 286.
} 
to consider the United States as a superpower. However, such widespread public opinion is not shared by Russian academic Evgeny Primakov, who contends that, "a superpower is determined not by consensual description... it is a conglomeration of states, which ensures its own security and dictates the rules of the game." ${ }^{2}$ According to Primakov, the United States does not satisfy these requirements and therefore does not qualify as a superpower. The opposite opinion, that the United States is a superpower, is much more common. This is true especially in the United States. ${ }^{3}$ In reality, the U.S. dictates the rules of the game: from 1890 to 2001, the U.S. used armed intervention 134 times and imposed sanctions to 75 countries, or 52 percent of humanity. ${ }^{4}$ In "The Opportunity: America's Moment to Alter History's Course" R. Haass asserts that the world today can be characterized by the blatant misbalance of American superiority over the rest of the world. ${ }^{5}$ Consequently, this opinion is shared not only by intellectual circles but by the public at large. In Ivan Krastev's words, it has become a "master framework."

The European version of anti-Americanism is based on ideological, cultural and political reasons unique to European countries. As J.F. Revel stresses, "the hatred of the liberal civilization... is based on the anti-American idée fixée and we should look to the remote past for its sources." ${ }^{6}$ Thus, European anti-Americanism appeared long before the U.S. became a global superpower, and perhaps before it even came into being. In any case, we cannot attribute this phenomenon to only the last decade when the United States became subject to unprecedented European criticism. Some analysts give their opinion that there is nothing new in European anti-Americanism and anti-European

\footnotetext{
${ }^{2}$ Primakov, E. The World after September, $11^{\text {th }}$ and The Invasion of Iraq. Ekaterinbourg: 2003, pp.138-139.

${ }^{3}$ see Hardt, M. and Negri, A., Empire, Cambridge (Ma) and London: Harvard Univ. Press, 2000, p.180; Boot, M., "America's Destiny is to Police the World" in: Financial Times, February 18, 2002, p. 15.

${ }^{4}$ Sardar, Z. and Davis, M. W., Why Do People Hate America? Cambridge: Icon Books, 2002, pp. 68-79.

${ }^{5}$ Haass, R., The Opportunity: America's Moment to Alter History's Course, New York: Public Affairs, 2005, p. 8.

${ }^{6}$ Revel, J.-F., L'Obsession anti-américaine. Son fonctionnement, ses causes, ses inconséquences. Paris : 2002, p. 98.
} 
moods in America. As far back as 1953, French philosopher J.P. Sartre asserted to European left circles that the United States suffers from "rabies". 7

Anti-Americanism is notable concerning several different spheres: social, economic, domestic and foreign policy. Concerning the social and economic component, the American economic model has little in common with the socially oriented economics of Europe; there is a significant divide between American and European values. As Samir Amin writes in The Liberal Virus: Permanent War and the Americanization of the World, "European political culture since the French Revolution has given a central place to values of equality, the American state has developed to serve the interests of capital alone." ${ }^{8}$ In other words, the American dream is based on individualism and economic efficiency while the European dream is based on values such as universalism, the dominant idea of common good and welfare state, the economics of participation, secularity, quality of life, sustainable development, multiculturalism, interdependency and compromise. Research carried out in European countries after 2004 (the year of President George Bush's reelection), indicated that Europeans have begun to question such values of community. ${ }^{9}$ There are no appropriate correlates in Europe for the American interpretations of economic success, liberty, and democracy.

Concerning the U.S.' domestic policy, Anti-Americanism manifests itself in three ways. Firstly, Europeans are skeptical of liberal democracy's ability to function. Secondly, this skepticism is enhanced by what is considered an archaic bi-partisan electoral system, which is foreign to the European multi-party model. Thirdly, there is a

\footnotetext{
${ }^{7}$ Cited by: Franquel, G., The Anti-Americanism: The Political Mainstream in Europe, www.inopressa.ru (accessed on 17.03.2006).

${ }^{8}$ Samir Amin S., The Liberal Virus: Permanent War and the Americanization of the World, Moscow: Europe Publishing House, 2006 (abstract of the Russian edition available at: http://www.europublish.ru/eng/allbooks/144377368, accessed on 12.08.2005).

${ }^{9}$ Wilkinson, R., The European Anti-Americanism. Brussels, www.voanews.com, (accessed on 12.08.2005).
} 
Review of European and Russian Affairs vol. 3 issue 3/2007 ( RERA 2007 all rights reserved

lack of transparency in American political life which further generates skepticism. As we know, the European electorate demands political transparency.

Regarding external affairs, anti-Americanism is generated in reaction to the U.S.' aggressive unilateral foreign policy. Much of the United States' foreign policy has completely disregarded the concerns of many European leaders, which has not only aided in undermining the legitimacy of the decision-making mechanisms of the United Nations, but has in turn provoked outright European irritation, to the bewilderment of Americans. From the European perspective that a global superpower is responsible to actively respond to global poverty, selfish intergovernmental agreements, and environmental degradation, the United States is not fulfilling its duties. Instead, it is cutting its aid to developing countries, is indifferent to international organisations, and refuses to subscribe to international environmental conventions, etc.

In his article "The USA is Surprised by European anti-Americanism”, Nikolay Zlobin notes that, "American foreign-policy elites are not morally ready for the European anti-Americanism. Americans reject the idea that they need to earn Europeans' confidence and bring their behaviour and thinking into correlation with the Old World. Obviously, the traditional differences in culture and history have more influence upon the relations between the two sides than during the Cold War. The main issues that divide Europe and America are a divergence of views on military force and the international problem solving." ${ }^{10}$ In contrast to the European approach, the United States increasingly gains confidence in its belief in using force to establish the so-called common liberal values of individual liberty, economic prosperity and democracy in the whole world. Europeans do not see military force as a means to achieving their foreign policy objectives.

\footnotetext{
${ }^{10}$ Zlobin, N., The USA is Surprised by the European Anti-Americanism, www.ng.ru, (accessed on 27.01.2003).
} 
International relations expert, Jerome Sheridan, considers that the cause of antiAmericanism is "a problem of overwhelming military superiority of the USA, their readiness for action and for using the military force. The Europeans think the Iraq war made the world less secure as long as it led to the appearance of a new generation of terrorists. By their opinion, America rash uses the military power without a moment's hesitation to the consequences for the other people and for the whole world". ${ }^{11}$

Not only does unprecedented use of military force antagonize other global actors, but the establishment of military bases outside of the U.S. spreads American cultural and social norms. Anti-Americanism is thus manifested on a cultural level, in reaction to stereotypes of the American lifestyle, which are popularized by mass media. According to public opinion polls conducted by the Pew Research Centre, despite a penchant to consume products of American mass culture, the majority of Europeans are displeased with the growth of American views and behaviours. ${ }^{12}$

In sum, scepticism of liberal democracy and the bipartisan American political system; hegemonic foreign policy and a preference for military force; and a dislike of the spread of the influence of American mass culture, all form the basis of AntiAmerican expansion.

According to J.F. Revel, anti-Americanism "is present in the whole world... including Europe, its birthplace, and in some capitals is an idée fixée or represents certain principles of foreign policy". ${ }^{13}$ Furthermore, anti-Americanism is divided everywhere in Europe. In general, Northern European countries are considered more sympathetic to the United States (Britain's attitude towards the United States is a topic for individual research) than Southern countries such as Italy and France. Vladislav

\footnotetext{
${ }^{11}$ Cited by Wilkinson, R., The European Anti-Americanism. Brussels, www.voanews.com, (accessed on 12.08.2005).

${ }^{12}$ Franquel, G., The Anti-Americanism: The Political Mainstream in Europe, www.inopressa.ru (accessed on 17.03.2006).

${ }^{13}$ Revel, J.-F., L'Obsession anti-americaine. Son fonctionnement, ses causes, ses inconsequences. Paris : 2002 , p. 114.
} 
Inozemtsev posits that France's treatment of the United States is "nearly indecent.", However, it is inaccurate to stereotype a stringent "North-South" divide. In Hatred Against America, based on a Norwegian case study, Bower claims that AntiAmericanism in Europe is rooted in the biased European media. "There is no doubt that the main obstacle for the improvement of our relations and mutual understanding is the European media establishment." 15 If Bower was right, mass media has been incredibly successful in accordance with the findings of the Pew Research Centre, which assert that the majority of Europeans want their governments to be more independent from Washington concerning diplomatic and external policy. ${ }^{16}$ In sum, "From its traditional roots in left intellectual circles, academics and café habitués, European antiAmericanism has spread into mainstream political culture." ${ }^{17}$

The role of, and the relationship between the EU and the U.S. in an age of globalization, are actively discussed by European thinkers, politicians and economists. Some of them are unapologetically anti-American. Will Hutton, in The World We Live In, supports a re-orientation of Great Britain's foreign policy towards Continental Europe. ${ }^{18}$ Benjamin Barber, authour of Fear's Empire and Jihad vs. McWorld, presents the idea of Pax Americana, the strategy of preventative war, which has contributed to anti-American attitudes around the globe. ${ }^{19}$

Thinkers in opposition to this idea, such as Bruce Bower and J.F. Revel, seek to deflate the stereotypes upon which "vulgar anti-Americanism" is based. The majority of American social scientists does not take issue with the ideological divide between Europe and the U.S., and seek to share world hegemony. According to Fred Bergsten in

\footnotetext{
${ }^{14}$ Inozemtsev, V., Is Europe Really Possessed by Anti-Americanism?, Moscow: 2005, p. 294.

${ }^{15}$ Bower, B., The Hatred Against America, Atlantic Diary, www.svoboda.org, (accessed on 13.07.2004).

${ }^{16}$ Wilkinson, R., The European Anti-Americanism. Brussels, www.voanews.com, (accessed on 12.08.2005).

${ }^{17}$ Franquel, G., The Anti-Americanism: The Political Mainstream in Europe, www.inopressa.ru (accessed on 17.03.2006).

${ }^{18}$ Hutton, W., The World We Live In. Moscow : 2004.

${ }^{19}$ Barber, B., Fear's Empire. War, Terrorism, and Democracy, New York and London: 2003.
} 
Review of European and Russian Affairs vol. 3 issue 3/2007 ( RERA 2007 all rights reserved

G2: The Best Way to Go, the EU is an international economic and political leader, which together with the United States, should form an informal advisory body (Bergsten's G2), as a basis for all intergovernmental organisations (such as the G8, IMF and WTO) concerning global decision-making. In advocating that all intergovernmental organisations form such a basis, Bergsten essentially suggests that the EU and the United States need only manage global economics. ${ }^{20}$

At the heart of this article is the question of whether anti-Americanism is an effective contributor to the European integration process. In its institutional form, the European Union is much less anti-American than Europe as a community of nationstates that draw some of their identity from negative American rhetoric. Critics assert that anti-Americanism is a convenient excuse for policy and ideological shortcomings.

A United Europe can be identified as an association equal to the U.S. in the international arena. So much so, that during the negotiations of the EU treaties, the representatives of the member states had difficulty defining this new suprastate body. The negation and opposition of American values represents an important step in the attempt to define the nature of the EU, an original organisation in itself. AntiAmericanism identifies common characteristics unique to European countries alone. Without doubt, Europe needs to find this common denominator.

Therefore, when Europe defines its unique identity, it must replace vulgar antiAmericanism with a respectful anti-Americanism that recognizes the U.S.' political culture. The European identity is certainly in crisis. However, as Russian political scientist Gleb Pavlovsky writes, "The European idea of an integrated Europe will

\footnotetext{
${ }^{20}$ Bergsten, C. F., G2: The Best Way to Go: The Partnership Principle, Ew Forms of Governance in the 21st Century. Alfred Herrhausen Society for International Dialogue. Archetype Publications : London, 2004, pp. 323-324.
} 
Review of European and Russian Affairs vol. 3 issue 3/2007 @ RERA 2007 all rights reserved

survive crisis and likely come out victorious, established, and even more expansionist.",21

It is likely that if the ideology of 'europeism', some kind of utopia or myth about the European integration process, came true, it would be positive and constructive. This concept of utopia, as the forerunner of a project, creates strong societal bonds. According to Vaclav Klaus, for some, the concept of 'europeism' "became a new alternative, a modern liberalism or a post-liberal ideology" ${ }^{22}$ World War II triggered "a modification of political thought and a political mind shift towards internationalism and universalism" ${ }^{23}$ and, thus, a shift towards 'europeism'.

In Has History Restarted Since September 11, Francis Fukuyama writes that the surrender of individual states' national sovereignty to the supranational organisation of the EU demonstrates their faith in the end of history. ${ }^{24}$ 'Europeism' is essentially a collective ideology, which advocates a break with individualism and calls upon a democratic suprastate. The basic question is whether such a state could be a real and efficient democracy.

\footnotetext{
${ }^{21}$ Pavlovsky, Gleb. Preface, in Europe without Russia. European Constitutional Treaty of 20 October 2004. Moscow: 2005, p. 5.

${ }^{22}$ Klaus, V. Why I am not an "europeist", in Europe without Russia. European Constitutional Treaty of 20 October 2004. Moscow: 2005, p. 9.

23 Klaus, V. Why I am not an "europeist", in Europe without Russia. European Constitutional Treaty of 20 October 2004. Moscow: 2005, p. 12.

${ }^{24}$ Fukuyama F., Has History Restarted Since September 11, CIS, Sydney: 2002.
} 


\section{Bibliography}

Barber, B., Fear's Empire. War, Terrorism, and Democracy, New York and London: 2003.

Bergsten, C. F., G2: The Best Way to Go: The Partnership Principle, Ew Forms of Governance in the 21st Century. Alfred Herrhausen Society for International Dialogue. Archetype Publications : London, 2004.

Franquel, G., The Anti-Americanism: The Political Mainstream in Europe, www.inopressa.ru (accessed on 17.03.2006).

Fukuyama F., Has History Restarted Since September 11, CIS, Sydney: 2002.

Haass, R., The Opportunity: America's Moment to Alter History's Course, New York: Public Affairs, 2005.

Hardt, M. and Negri, A., Empire, Cambridge (Ma) and London: Harvard Univ. Press, 2000, p.180; Boot, M., "America's Destiny is to Police the World" in: Financial Times, February $18,2002$.

Hutton, W., The World We Live In. Moscow : 2004.

Inozemtsev, V., Is Europe Really Possessed by Anti-Americanism?, Moscow: 2005.

Klaus, V. Why I am not an "europeist", in Europe without Russia. European Constitutional Treaty of 20 October 2004. Moscow: 2005.

Pavlovsky, Gleb. Preface, in Europe without Russia. European Constitutional Treaty of 20 October 2004. Moscow: 2005.

Primakov, E. The World after September, $11^{\text {th }}$ and The Invasion of Iraq. Ekaterinbourg: 2003.

Revel, J.-F., L'Obsession anti-américaine. Son fonctionnement, ses causes, ses inconséquences. Paris: 2002.

Samir Amin S., The Liberal Virus: Permanent War and the Americanization of the World, Moscow: Europe Publishing House, 2006.

Sardar, Z. and Davis, M. W., Why Do People Hate America? Cambridge: Icon Books, 2002.

Wilkinson, R., The European Anti-Americanism. Brussels, www.voanews.com, (accessed on 12.08.2005).

Zlobin, N., The USA is Surprised by the European Anti-Americanism, www.ng.ru, (accessed on 27.01.2003). 